\title{
Phytochemical Investigation, Liquid Chromatography- Mass Spectrometry Analysis, Antibacterial and Anthelminthic Activity of Lindernia crustacea (L.) F. Muell.
}

\author{
S. S. GHORI*, FOUZIA TEHSEEN', S. S. SULTANA, NOUSHEEN FATIMA AND M. M. AHMED \\ Department of Pharmacology, ${ }^{1}$ Department of Pharmaceutical Chemistry, Anwarul Uloom College of Pharmacy, Hyderabad, \\ Telangana 500001, India
}

Ghori et al.: Antibacterial and Anthelminthic Activity of Lindernia crustacea (L.) F. Muell.

Lindernia crustacea (L.) F. Muell is one of the commonly used medicinal plants native to India, Indonesia and Malaysia. In the present investigation antibacterial activity of leaf and stem petroleum ether and methanolic extracts was performed at $25 \mu \mathrm{g} / \mathrm{ml}, 50 \mu \mathrm{g} / \mathrm{ml}, 75 \mu \mathrm{g} / \mathrm{ml}$ and $100 \mu \mathrm{g} / \mathrm{ml}$ concentrations and anthelminthic activity of leaf methanolic extract was performed at $25 \mu \mathrm{g} / \mathrm{ml}, 75 \mu \mathrm{g} / \mathrm{ml}$ and $100 \mu \mathrm{g} / \mathrm{ml}$ concentrations. The powdered leaf and stem were extracted by soxhlation and the phytochemical screening of the extracts was performed for detection of phytoconstituents. The leaf petroleum ether and methanolic extracts showed the presence of alkaloids, carbohydrates, tannins and glycosides, whereas the stem petroleum ether and methanolic extracts showed alkaloids, carbohydrates, flavonoids and tannins. Antibacterial activity was performed by cup and plate method using Staphylococcus aureus and Escherichia coli with Penicillin G as standard. Antibacterial activity was not found in both stem and leaf extracts. Anthelminthic activity was performed using Indian earthworm, with albendazole as standard drug. The leaf methanolic extract showed significant anthelminthic activity at $100 \mu \mathrm{g} / \mathrm{ml}$ with paralysis time of $58 \pm 3.978$ and death time of $79 \pm 4.796$ as compared with standard drug. The anthelminthic activity of methanolic extract might be due the presence of phytoconstituents as identified by liquid chromatography-mass spectrometry analysis.

Key words: Lindernia crustacea, extract, phytoconstituents, antibacterial, antihelminthic 
Medicinal plants have been recognised as an excellent source of naturally occuring antimicrobial compounds which can be beneficial in the productive treatment of tricky bacterial infections ${ }^{[1]}$. According to World Health Organisation (WHO), medicinal plants are operative source to acquire a variety of drugs ${ }^{[2]}$. Plants produce a library of compounds as protective tools against pathogens and hence are a potential source of antimicrobial substances ${ }^{[3]}$. Plants are a natural source of compounds used in the treatment of infectious diseases prevailing in the society ${ }^{[4]}$. Plants and their derived product are used by mankind since ancient times as home remedies ${ }^{[5]}$. Researchers have proved that plants contain various bioactive constituents which are responsible for combating diseases ${ }^{[6]}$. A number of plants have antimicrobial activity as a result of the synthesized secondary metabolities ${ }^{[7,8]}$. Several traditional plants are used as medicines for the treatment due to lesser side effects. Microbes play a major role in ecosystem because they act as decomposers. Antimicrobials are drugs that kill microorganisms or stops their multiplication or growth. Anthelminthics are a class of antiparasitic drugs that expel the parasitic worms and other helminth parasites from the body by killing them without causing any significant effect or damage to the host. Lindernia crustacea (L. crustacea) is an annual herb belonging to family linderniaceae which is used medicinally throughout the world. Apart from India, it is commonly used in Indonesia and Malaysia as medicine. It is used to treat ear ache ${ }^{[9]}$, injury, fever and thrush ${ }^{[10]}$, anti-inflammatory for skin to relieve itching, boils, sores, dysentery, ringworm ${ }^{[11,12]}$ which needs to be explored yet. It is found to be an effective against various rodents ${ }^{[13]}$. It is also reported to show anticancer ${ }^{[14]}$ and antioxidant ${ }^{[15]}$ activities. Many other species of the same family have been reported for antimicrobial and anthelminthic activity. L. anagallis has shown antimicrobial activity against Staphylococcus aureus $^{[16]}$. Similarly L. madayiparensi has been reported for anthelminthic activity against Indian earthworm ${ }^{[17]}$. Moreover the phytochemical screening data of the $L$. crustacea earlier reported showed the presence of various phytoconstituents. In the present work an attempt was made to screen the antibacterial and antihelminthic activity of leaf and stem extracts of the plant. The plant material was collected from local plant supplier and was authenticated and given voucher no. 237 by Department of Botany, Osmania University, Hyderabad, Telangana, India. All the chemicals and solvents used were procured from a certified chemical supplier. The solvents used were of analytical reagent grade, FINAR (Batch No: 340400210BU). The leaves and stems of $L$. crustacea were washed to make them free from soil and dust and were dried under shade for about 5-7 $d$ and then weighed. The plant parts were grinded separately using mechanical grinder provided by Philips HI 1645750 watt and stored in air tight containers at room temperature for further use. The petroleum ether and methanol extracts of leaf and stem were obtained by using soxhlation. In the present study, $16.6 \mathrm{~g}$ of dried powder of leaves and stems were extracted by using $400 \mathrm{ml}$ of petroleum ether and methanol each at $50^{\circ}$ and $60^{\circ}$ respectively. The extracts were then concentrated using rotavapor at $45^{\circ}$ and $55^{\circ}$ and stored in air tight containers for further investigation. Phytochemical investigation was performed for both leaf and stem extracts for the presence of phytoconstituents using standard qualitative methods ${ }^{[18]}$. The leaf extract was analysed by Liquid Chromatography-Mass Spectrometry (LC-MS) analysis for identification of different chemical components. LC-MS was performed by standard procedure using Column-Symmetry $\mathrm{C}_{18}(4.6 \times 150 \mathrm{~mm}, 5 \mu \mathrm{m}$ particle size). The sample $(10 \mu \mathrm{l})$ is injected after diluting with methanol directly into the source by the flow injection method using Acetonitrile (ACN):water (74:26\% v/v) as mobile phase at a flow rate of $1.7 \mathrm{ml} / \mathrm{min}$. The mass spectra were recorded in Electrospray Ionization (ESI) positive mode. Ultra-high purity nitrogen and helium were used as curtain and collision gases respectively. The typical ion source conditions were: nebulizer gas, $60 \mathrm{psi}$, dry temperature $400^{\circ}$, dwell time $200 \mathrm{~ms}$. The sample flow rate was $1.7 \mathrm{ml} / \mathrm{min}$, wavelength $225 \mathrm{~nm}$, column temperature $40^{\circ}$, with $10 \mu \mathrm{l}$ injection volume and a total run time on $7 \mathrm{~min}$. The procedure followed was cup plate method using nutrient agar media ${ }^{[19]}$. The antibacterial activity of petroleum ether and methanolic extract at $25 \mu \mathrm{g} / \mathrm{ml}$, $50 \mu \mathrm{g} / \mathrm{ml}, 75 \mu \mathrm{g} / \mathrm{ml}$ and $100 \mu \mathrm{g} / \mathrm{ml}$ was tested using Staphylococcus aureus (gram positive strain) and Escherichia coli (gram negative strain) using Penicillin

\footnotetext{
This is an open access article distributed under the terms of the Creative Commons Attribution-NonCommercial-ShareAlike 3.0 License, which allows others to remix, tweak, and build upon the work non-commercially, as long as the author is credited and the new creations are licensed under the identical terms
}

Accepted 07 December 2021 Revised 06 April 2021 Received 09 July 2020

*Address for correspondence E-mail: safiullahghori@gmail.com Indian J Pharm Sci 2021;83(6):1314-1319 
$\mathrm{G}$ as standard. A sterile borer was used to prepare 3 cups of $8 \mathrm{~mm}$ diameter in the medium of each petri dish. The centre cup was taken as standard, its zone of inhibition was measured for comparison with test drug. The compound to be tested was transferred into the wells by using micro pipette. Every time the tip was discarded and another clean tip was used for the new compound. The plates were incubated for 12-24 h and the zone of inhibition was measured. The assay was performed on Indian earthworm. $20 \mathrm{ml}$ formulation containing three different concentrations $(25,75,100$ $\mu \mathrm{g} / \mathrm{ml}$ ) in distilled water were prepared. The test solution and standard drug solution were freshly prepared and time of paralysis was noted when no movement of any sort could be observed except when worms were shaken vigorously. The time of death was recorded after ascertaining that the worms did not move when shaken vigorously. Albendazole $(15 \mu \mathrm{g} / \mathrm{ml})$ was used as reference standard and distilled water as the vehicle. The results of phytochemical screening data of the extracts of L. crustacea showed the presence of alkaloids, carbohydrates, flavonoids, tannins and glycosides. It can be seen that the petroleum and methanolic extract of the leaf and stem are excellent source of different phytochemicals. Both the leaf and stem extracts showed the presence of alkaloids, carbohydrates and tannins. The leaf extracts also shows the presence of glycosides whereas they are absent in stem extract. The results are shown in Table 1. The test solution showed no zone of inhibition, showing no antibacterial activity as shown in Table 2. Anthelminthic activity was investigated on methanolic extracts of leaf at $25 \mu \mathrm{g} / \mathrm{ml}, 75 \mu \mathrm{g} / \mathrm{ml}$ and $100 \mu \mathrm{g} / \mathrm{ml}$ concentrations. The methanolic leaf extracts showed anthelminthic effect in a dose dependant manner. Albendazole was taken as the reference standard. The methanolic leaf extract of L. crustacea caused paralysis at $58 \mathrm{~min}$ and death time $79 \mathrm{~min}$ at $100 \mu \mathrm{g} / \mathrm{ml}$ concentration as depicted in Table 3 . The active components were identified in the leaf extract of L. crustacea by LC-MS.

TABLE 1: PHYTOCHEMICAL SCREENING OF LEAF AND STEM EXTRACT OF L. crustacea

\begin{tabular}{|c|c|c|c|c|}
\hline Tests & Petroleum ether leaf & Methanol leaf & Petroleum ether stem & Methanol stem \\
\hline \multicolumn{5}{|l|}{ Test for Alkaloids } \\
\hline 1. Dragendroff's test & Positive & Positive & Positive & Positive \\
\hline 2. Wagner's test & Positive & Positive & Positive & Positive \\
\hline \multicolumn{5}{|l|}{ Test for carbohydrates } \\
\hline 1. Barfoed's test & Positive & Positive & Positive & Positive \\
\hline \multicolumn{5}{|l|}{ Test for Flavonoid } \\
\hline 1. Sulphuric acid test & Negative & Negative & Positive & Positive \\
\hline 2. Lead acetate test & Positive & Positive & Positive & Positive \\
\hline \multicolumn{5}{|l|}{ Test for saponins } \\
\hline \multicolumn{5}{|c|}{$\begin{array}{l}\text { Test for tannins and phenolic } \\
\text { compounds }\end{array}$} \\
\hline 1. Ferric chloride test & Positive & Positive & Positive & Positive \\
\hline 2. Lead acetate test & Positive & Positive & Positive & Positive \\
\hline 3. Gelatin test & Positive & Positive & Positive & Positive \\
\hline \multicolumn{5}{|l|}{ Test for glycosides } \\
\hline 1. Killerkilliani & Positive & Positive & Negative & Negative \\
\hline 2. Salkowski & Positive & Positive & Positive & Negative \\
\hline
\end{tabular}

TABLE 2: ANTIBACTERIAL ACTIVITY OF LEAF AND STEM PETROLEUM ETHER AND METHANOLIC EXTRACTS OF L. crustacea

\begin{tabular}{|c|c|c|c|c|c|c|c|c|c|c|c|c|c|c|c|c|}
\hline \multirow{3}{*}{$\begin{array}{l}\text { Bacterial } \\
\text { strains }\end{array}$} & \multicolumn{4}{|c|}{$\begin{array}{l}\text { Petroleum ether } \\
\text { leaf extract }\end{array}$} & \multicolumn{4}{|c|}{$\begin{array}{c}\text { Methanolic leaf } \\
\text { extract }\end{array}$} & \multicolumn{4}{|c|}{$\begin{array}{c}\text { Petroleum ether } \\
\text { stem extract }\end{array}$} & \multicolumn{4}{|c|}{$\begin{array}{c}\text { Methanolic stem } \\
\text { extract }\end{array}$} \\
\hline & 25 & 50 & 75 & 100 & 25 & 50 & 75 & 100 & 25 & 50 & 75 & 100 & 25 & & 75 & 100 \\
\hline & $\mu \mathrm{g} / \mathrm{ml}$ & $\mu \mathrm{g} / \mathrm{ml}$ & $\mu \mathrm{g} / \mathrm{ml}$ & $\mu \mathrm{g} / \mathrm{ml}$ & $\mu g / m l$ & $\mu \mathrm{g} / \mathrm{ml}$ & $\mu \mathrm{g} / \mathrm{ml}$ & $\mu \mathrm{g} / \mathrm{ml}$ & $\mu \mathrm{g} / \mathrm{ml}$ & $\mu \mathrm{g} / \mathrm{ml}$ & $\mu \mathrm{g} / \mathrm{ml}$ & $\mu g / m l$ & $\mathrm{ml}$ & $\mathrm{ml}$ & $\mathrm{ml}$ & $\mathrm{ml}$ \\
\hline $\begin{array}{l}1 \text { Escherichia } \\
\text { coli }\end{array}$ & - & - & - & - & - & - & - & - & - & - & - & - & - & - & - & - \\
\hline 2 Staphylococci & - & - & - & - & - & - & - & - & - & - & - & - & - & - & - & - \\
\hline
\end{tabular}


The compounds were identified by their molecular peaks and retention time as shown in fig. 1 and Table 4 respectively. A novel approach has been performed for quantification of the plant. LC-MS interpretation was performed using standard spectrum database. LC-MS chromatogram is shown in fig. 2. It was found that five different constituents were identified which were further separated to estimate their amount of percentage in the plant part. All the identified compounds were chloro and nitro derivatives as shown in Table 5. In the present study, petroleum ether and methanolic extracts of leaf and stem of the plant were investigated for antibacterial activity and methanolic extract of leaf for anthelminthic activity. The extracts did not show antibacterial activity. However, it can be further investigated against other bacterial and fungal strains. There was promising anthelminthic activity which was dose dependant. Earthworms are used widely for initial

TABLE 3: ANTHELMINTIC ACTIVITY OF METHANOLIC EXTRACT OF L. crustacea LEAF

\begin{tabular}{|c|c|c|c|c|}
\hline \multirow{2}{*}{ Time (min) } & Test dose & Test dose & Test dose & Standard \\
\hline & $(25 \mu \mathrm{g} / \mathrm{ml})$ & $(75 \mu \mathrm{g} / \mathrm{ml})$ & $(100 \mu \mathrm{g} / \mathrm{ml})$ & $(15 \mu \mathrm{g} / \mathrm{ml})$ \\
\hline Paralysis time & $67 \pm 5.6663$ & $59.125 \pm 6.212$ & $58 \pm 3.978$ & $25 \pm 0.000$ \\
\hline Death time & $112 \pm 4.692$ & $109.25 \pm 8.182$ & $79 \pm 3.726$ & $38 \pm 0.000$ \\
\hline
\end{tabular}

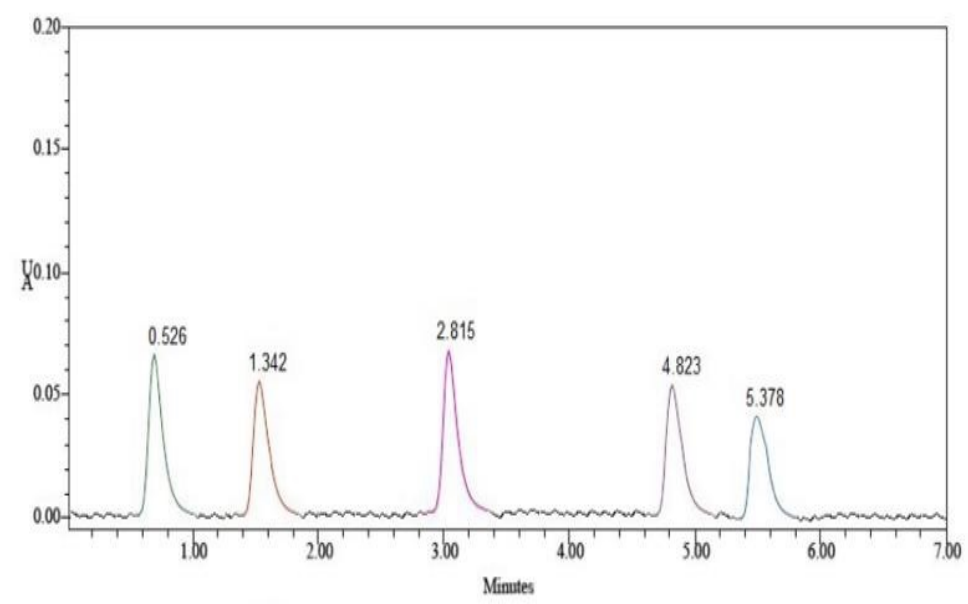

Fig. 1: LC-MS analysis of methanolic leaf extract of $L$. crustacea

\section{TABLE 4: RETENTION TIME $\left(R_{t}\right)$ OF METHANOLIC LEAF EXTRACT OF L. crustacea}

\begin{tabular}{lccccccc}
\hline S. No & Name & $\mathbf{R}_{\mathbf{t}}$ & Area & Height & USP plate count & USP Tailing & Percentage Found \\
\hline 1 & Component 1 & 0.526 & 34724 & 58631 & 5043 & 1.1 & $25.38 \%$ \\
2 & Component 2 & 1.342 & 25080 & 34821 & 5432 & 1.2 & $18.33 \%$ \\
3 & Component 3 & 2.815 & 34536 & 58451 & 5987 & 1.4 & $25.24 \%$ \\
4 & Component 4 & 4.823 & 24866 & 34710 & 5845 & 1.2 & $18.17 \%$ \\
5 & Component 5 & 5.378 & 17574 & 21247 & 5371 & 1.1 & $12.84 \%$ \\
Mean & & 27356 & & & & \\
Standard deviation & & & 7295.677 & & & & \\
\hline
\end{tabular}

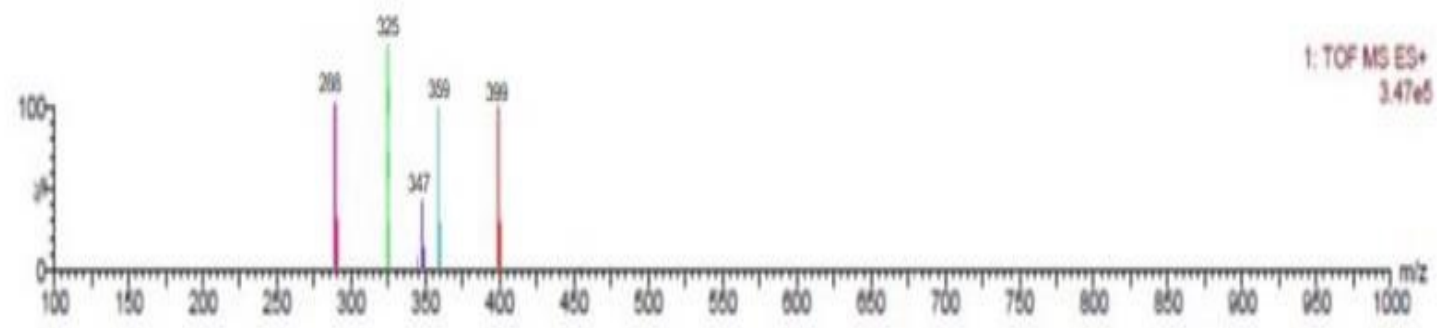

Fig. 2: LC-MS chromatogram of methanolic leaf extract of $L$. crustacea 


\begin{tabular}{|c|c|c|c|c|}
\hline $\begin{array}{l}\text { Observed } \\
\text { ion mass } \\
\text { (Da) }\end{array}$ & Proposed formula & Predicted Name & Predicted Structure & Calculated Weight \\
\hline 288 & $\mathrm{C}_{6} \mathrm{H}_{6} \mathrm{Cl}_{6}$ & 2,2,3,4,5,5-Hexachloro-3-hexene & & 290.83 \\
\hline 325 & $\mathrm{C}_{11} \mathrm{H}_{10} \mathrm{Cl}_{3} \mathrm{NO}_{4}$ & $\begin{array}{c}\text { Diethyl 3,4,5-trichloropyridine-2,6- } \\
\text { dicarboxylate }\end{array}$ & & 326.56 \\
\hline 347 & $\mathrm{C}_{10} \mathrm{H}_{13} \mathrm{Cl}_{3} \mathrm{NO}_{2} \mathrm{PS}$ & $\begin{array}{l}\text { O-Ethyl 0-(2,4,6-trichlorophenyl) } \\
\text { ethylphosphoramidothioate }\end{array}$ & & 348.61 \\
\hline 359 & $\mathrm{C}_{15} \mathrm{H}_{22} \mathrm{INO}$ & $\begin{array}{l}\text { 8-lodo-N-(4-methylphenyl) } \\
\text { octanamide }\end{array}$ & & 359.24 \\
\hline 399 & $\mathrm{C}_{23} \mathrm{H}_{36} \mathrm{~F}_{3} \mathrm{NO}$ & $\begin{array}{c}\text { Benzamide, N,N-bis(2-ethylhexyl)- } \\
\text { 2,3,4-trifluoro- }\end{array}$ & & 399.53 \\
\hline
\end{tabular}

in vitro anthelminthic investigation studies ${ }^{[20]}$. The anthelminthic activity can be attributed to the presence of phenolic compounds and tannins in the extract. Polyphenolic compounds and tannins in general show anthelminthic activity. Some synthetic phenolic antihelminthics for e.g. Niclosamide, oxyclozanide and Bitionol are shown to interface with energy generation in helminth parasites by uncoupling oxidative phoshorylation. The effect of albenzadole on the worms is to cause flaccid paralysis those results in expulsion of the worms by peristalsis. It acts by increasing chloride ion conductance of worm muscle membrane producing hyperpolarisation and reducing excitability which leads to muscle relaxation and flaccid paralysis ${ }^{[21]}$. A novel approach has been performed for quantification of the plant. The LC-MS analysis of the extracts revealed the presence of number of compounds which were evident by their molecular peaks. However further isolation and characterisation of the compounds can be carried out. Antibacterial activity was not found in both stem and leaf extract. This may be due to resistance of extract to the specific microorganisms used in procedure. However, the extracts can be tested for antimicrobial activity by using other strains of gram positive and gram negative bacteria. The leaf methanolic extract of L. crustacea showed significant anthelminthic activity at all the tested doses when compared to control as vermifuge and vermicidal drug while the highest activity was shown at the highest concentration $(100 \mu \mathrm{g} / \mathrm{ml})$. Hence, this plant can be an alternative source of anthelmintic drug and can generate new active leads. The LC-MS analysis showed the presence of various compounds which may be responsible for anthelminthic activity.

\section{Acknowledgements:}

We are thankful to Dr. Nadeem Fatima, Head, Department of Biotechnology, Anwarul Uloom PG College, Hyderabad, India and Mrs. Sameena, Assistant Professor, Anwarul Uloom College of Pharmacy, India for providing research facilities for antimicrobial studies.

\section{Conflicts of interest:}

The authors declare that they have no conflicts of interest. 


\section{REFERENCES}

1. Iwu MW, Duncan AR, Okunji CO. New Antimicrobials of Plant Origin in. Perspectives on New Crops and New Uses. In: Janick J ed. Plant Breeding Reviews, ASHS Press, Alexandria, Virginia; 1999.

2. WHO Traditional Medicine Strategy. World Health Organization. Geneva; 2002.

3. Sridhar N, SuryaKiran BVVS, Sasidhar DT, Kanthal LK. In vitro Antimicrobial screening of methanolic extracts of Cleome chelidonni and Cleome gynandra. Bangladesh $\mathrm{J}$ Pharmacol 2014;161-6.

4. Rajkumar K, Malathi R. Phytochemical investigation GC-MS analysis and in vitro antimicrobial activity of Coleus forskohlii. Bangladesh J Pharmacol 2015;10:924-30.

5. Medina AL, Lucero ME, Holguin FO, Estell RE, Posakony JJ, Simon J, et al. Composition and antimicrobial activity of Anemopsis californica leaf oil. J Agric Food Chem 2005;53(22):8694-8.

6. Romero CD, Chopin SF, Buck G, Martinez E, Garcia M, Bixby L. Antibacterial properties of common herbal remedies of the southwest. J Ethnopharmacol 2005;99(2):253-7.

7. Saha MR, Debnath PC, Rahman MA, Anwarulislam M. Evaluation of in vitro anthelminthic activities of leaf and stem extracts of Justicia gendarussa. Bangladesh J Pharmacol 2012;7(1):50-3.

8. Vigar Z. Atlas of medicinal of parasitology. P. G. Publishing house, Singapore; 1984. p. 217.

9. Usher G. A dictionary of plants used by Man. London: Constable \& Company Ltd.; 1974.

10. Marina S, Jatna S, Eko BW, Nisyawati N. Local Knowledge of Medicinal Plants in sub-ethic Batak Simalungan of North Sumatra, Indonesia. Biodiversitas 2015;5:45-54.

11. Williams CJ. Medicinal Plants in Australia; 2013.

12. Swapna MM, Prakash KR, Anoop KP, Manju CN, Rajith NP.
A review on the medicinal and edible aspects of some aquatic and wetland plants of India. J Med Plant Res 2011;5(33):716376.

13. Smriti Rekha CD, Ahmed AB, Saha D, Chanda I. Scientific Evidence of Lindernia crustacea (L) F. Muell, an indigenous plant: folklore medicine used traditionally. Int Res J Pharm 2019;10(1):176-83.

14. Barusrux S, Preeyakul NW, Chaiyanan PPP, Khamphio M, Tanthanuch W, Thummanu K. Investigation of Anticancer activity of Lindernia crustacea (L.) F. Muell. var. Crustacean. Walailak J Sci Tech 2019;16(5):307-17.

15. Smriti Rekha CD, Ahmed AB, Shil D, Chanda I. Isolation and In vitro Antioxidant activity of Flavanoid from Lindernia crustacea (L) F. Muell. Asian J Pharm Clin Res 2019;12(6):28993.

16. Tsai ML, Lin CX, Lin WC, Yang CH. Antimicrobial, antioxidant and anti-inflammatory activities of essential oils from five selected herbs. Biosci Biotechnol Biochem 2011;75(10):1977-83.

17. Chiranjeevi U, Kamarajan K, Manna PK. Investigation of in vitro anthelmintic activity of Lindernia madayipaarense. Res J Pharm Tech 2018;11(1):183-6.

18. Kokate CK, Gokhale SB. Practical Pharmacognosy; 2009.

19. Mukti RF, Chowdhury MMK, Nahid MA, Rahaman MM. Antibacterial activity and physicochemical Property of Florally diversified Bangladeshi Honey. Bangladesh J Microbiol 2016;33.

20. Sobiyi OK, Ashafa OT. In vitro anthelminthic activity of Heliotropium indicum, Senna fistula and Spigelia anthelmia used as worm expeller in South West Nigeria. Bangladesh J Pharmacol 2015;10(2):417-22.

21. Hemamalini K, Rajani A, Reddy UV, Sundari ER. Anthelminthic activity of Methanolic leaf extract of Sophora interrupta. Int Res J Pharm 2013;4(8):148-50. 